COMMENTARY ON COVID-19 AND THE FoOd SYSTEM

\title{
A food nonprofit's response to COVID-19: The Common Market leans on its mission to serve
}

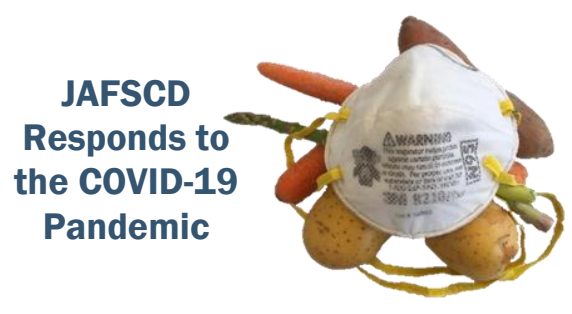

\author{
Caitlin M. Honan * \\ The Common Market
}

Submitted October 12, 2020 / Published online February 18, 2021

Citation: Honan, C. M. (2021). A food nonprofit's response to COVID-19: The Common

Market leans on its mission to serve. Journal of Agriculture, Food Systems, and Community

Development, 10(2), 279-282. https://doi.org/10.5304/jafscd.2021.102.009

Copyright (C) 2021 by the Authors. Published by the Lyson Center for Civic Agriculture and Food Systems. Open access under CC-BY license.

$\mathrm{T}$

he Common Market is a nonprofit regional food distributor with a mission to connect communities with good food from sustainable family farms. Outputs of their work include improved food security, farm viability, and community and ecological health. The nonprofit services communities in its three active regions - the Mid-Atlantic, the Southeast, and Houston, Texas - by delivering healthy farm food to the institutions that serve them: schools, hospitals, eldercare facilities, early childhood education centers, etc. As the COVID-19 pandemic struck the nation, it shut down some of the nonprofit's conventional wholesale outlets and exposed and intensified the issue of food insecurity throughout the country. The food hub prepared to lean on its mission intensely and creatively under these unprecedented circumstances. Poised to test the limits of a regional food system, The Common Market unveiled the resilient spirits of its team, its partners, and the family farms that make up its network. This essay highlights partnerships that ignited meaningful impact for their farmer partners and helped meet the needs of vulnerable populations amidst the pandemic.

"In the pandemic economy, nearly one in eight households doesn't have enough to eat. The lockdown, with its epic lines at food banks, has revealed what was hidden in plain sight: that the struggle to make food last long enough, and to get food that's healthful—what experts call 'food insecurity'-is a persistent one for millions of Americans." (Kenneally, 2020)

* Caitlin M. Honan, Communications, The Common Market; 428 East Erie Avenue; Philadelphia, PA 19134 USA; caitlin@,thecommonmarket.org 
These words kicked off a photo essay produced by The New York Times from September 2, 2020, months after the COVID-19 pandemic swept through our nation. It is these harsh, difficult-to-stomach realities that The Common Market hopes to rectify through each partnership, through each delivery, and through each and every case of food.

The Common Market's mission is to connect communities with good food from sustainable family farms. Our food nonprofit's successes reflect improved food security, community and ecological health, and farm viability.

As a pandemic hit our nation and exposed and intensified food insecurity throughout the country, we knew we'd be leaning on this mission intensely. A few weeks into 2020, we were poised to test the limits of a regional food system — and ultimately prove its resilience.

Our teams, based in Philadelphia, Atlanta, and Houston, pivoted quickly in response to COVID-19 and the immediate needs of our partners. The ecosystem of organizations and support that came together to keep our communities fed was remarkable-from farmers to foundations, from public policy to community pantries. This collective effort contributed to more than 915,000 individual boxes of good food distributed, the purchase of more than 10 million pounds ( 4.5 million $\mathrm{kg}$.) of produce, dairy, and proteins, and the support of nearly 100 family farms over the course of six months.

In mid-March 2020, we spoke directly and candidly with our farmer networks. Challenges around their crop plans and futures were flung at them with full force. How could they keep their families and staff working? How would they adapt? What portion of their markets could we help preserve?

"At our first board meeting following the outbreak, we questioned as a group: 'What should we do? Plant less?", shared Geoff Bucknum, operations and sales coordinator with Sunny Harvest, a longtime farmer partner of ours located in Kirkwood, Pennsylvania.

"The rational parts of our brains thought that we had to reduce potential waste. But then all of our instincts said: 'We need to press on."'

We knew that our vulnerable communities facing hunger would be finding themselves in dire situations, too. Even normally food-secure individuals and families would be entering into new, unstable territory. We saw this firsthand.

"I am in my 60s and live in Jackson Heights in New York City in what is now the deadliest area of the Earth due to coronavirus. I remain healthy, but don't wish to walk outside and signed up for a free food delivery service operated by the City of New York.

"Some of the food I had received was poor quality, canned and sugary. But yesterday your box came with fresh bread, dried beans, potatoes, a beet, kale, canned crushed tomatoes, and Cheddar cheese.

"My first thought was that someone wants me to live and it almost brought tears to my eyes.

"Thank you so very much for helping me and I am glad we in New York can be an outlet for your farmers."

Our team received this email message from a New Yorker named Janice in mid-April, about one month after the COVID-19 pandemic landed and threatened our communities.

Our Mid-Atlantic chapter signed a contract with New York City in April to deliver boxed food as part of its GetFood NYC COVID-19 Emergency Food Distribution Program, an effort to provide nourishment to sheltered-in-place New Yorkers (City of New York, 2020).

Overnight, our drivers became frontline workers; our teams, spanning all departments, and our farmer partners became more essential than ever.

In advance of and in preparation for relationships like this one, our teams put their heads together 
and worked alongside our farmers to conceive the "Farm-Fresh Box Program."

The program is designed to be a safe solution to food access for organizations looking to provide their communities with individualized boxed fruits, vegetables, and other healthy, culturally appropriate foods. Our Farm-Fresh boxes came delivered in a food-safe, self-contained box that required minimal handling and maximum efficiency. In addition to nourishment and community food access, it would provide much-needed revenue for our family farms.

To bring this weekly sustenance to New Yorkers, The Common Market Mid-Atlantic leveraged its farmer and producer network, which includes Lost Bread Co., a Philadelphia-based baker. Each New York City box contained one loaf of its freshly baked bread made with local grain.

"We saw news about food insecurity, even in areas that aren't typically food insecure," shared Lost Bread founder Alex DuBois. "This cemented our desire to make food as efficient and nutritious as possible."

The contract was mutually beneficial as it allowed Lost Bread Co. to bring back its formerly furloughed team.

Our weekly deliveries to New York City would include upward of 13,000 boxes filled with bread, cheese, black beans, potatoes, and a seasonal rotation of fruits and vegetables. Drops to Queens and Brooklyn were received by members of the National Guard who helped break down our pallets and load our boxes into taxis and limos that were prepared to deliver the free food to people's homes. In Manhattan, they set up drive-through tents for in-person distribution.

By the end of August 2020, our teams had distributed more than 215,341 boxes in New York City, representing 1.94 million meals total.

"This program has been a success on many levels," shared Nolan Masser of Red Hill Farm—500 acres (202 ha) of Pennsylvania farmland, located in Pitman, PA.

"Most of our potatoes are grown to make fresh-cut fries at restaurants and events. In March, that business disappeared. The food box programs allowed our potatoes to provide nutritious meals for those in need instead of going to waste. As a result, we were able to continue our operations and keep employees working who would have otherwise been laid off."

A regional food system shined bright. Similar contracts and partnerships would soon manifest for our nonprofit food hub.

Our Southeast chapter signed a contract with the city of Atlanta to distribute boxed produce, meats, and more to homebound seniors through its Senior Food Assistance Program.

The weekly distribution saw 300 boxes, each representing one week worth of meals, delivered to doorsteps. By the end of August 2020, more than 4,237 boxes had been delivered, totaling 105,925 pounds $(48,047 \mathrm{~kg})$ of local food. This directly supported 42 local farmer partners.

Our Texas chapter distributed more than 7,300 Farm-Fresh boxes from April through August 2020 through community partnerships, including ones formed with the American Heart Association, the Texas Center for Local Food (Elgin, TX), Furlough Kitchen Houston, and the Sustainable Food Center (Austin).

Support from the Still Water Foundation and the Michael \& Susan Dell Foundation helped the Texas chapter provide additional food access through deliveries to the Central Texas Food Bank and Austin Independent School Districts, respectively.

"We expected to lose most of our crops due to breakdowns in the supply chain during the coronavirus crisis, but we were fortunate to partner with The Common Market to get our fresh produce directly to the communities that needed it the most," shared farmer partner Shakera Raygoza of Terra Preta Farm, located in Edinburg, TX.

The largest partnership to date came in the form of a United States Department of Agriculture 
(USDA) contract. In May 2020, The Common Market became an approved vendor of the USDA for its Farmers to Families Food Box Program. ${ }^{1}$

In just days, we created processes to maintain the massive shift in operations and assembled teams to help do the work of getting 50,000 Farm-Fresh boxes out every week to communities facing food insecurity in the Mid-Atlantic and Southeast regions.

Over the length of the USDA contract - we were approved for two rounds that ran from May through mid-September 2020_our nonprofit purchased and delivered more than 5.5 million pounds ( 2.5 million $\mathrm{kg}$ ) of local food, supported just under 100 local family farms, and delivered food to more than 220 local partners throughout our two regions.

“The integrity of each box was nothing short of: 'We care with purpose.' My husband—who was helping with the unloading from pallets—-made the comment, 'This is what's going to make the difference: access to fresh foods," shared Lily Pabian, executive director of WeLoveBuHi, an Atlanta-based nonprofit that advocates for immigrant communities. The organization received more than 250 boxes of fruits and vegetables through our Farmers to Families program on a weekly basis.

Just as these boxes served as a lifeline for so many individuals and families, they too kept our teams working, our farms fully engaged, and our spirits alive during such an uncertain time.

"For the farmers, it's been a win-win-providing support for those in need while also providing an opportunity to keep their farms afloat," shared farmer Howard Berk of Ellijay Mushrooms, a mushroom farm located in the foothills of the Appalachian Mountains. "The Common Market has given us a lifeline in these uncertain times with the opportunity to supply our mushrooms in the USDA boxes."

Support from federal and local governments aided our work and leveraged our impact substantially. Sustained support would have continued to aid those directly whose hunger didn't stop when the contracts did.

Yet, the loss of contracts didn't mean our work was done, and it certainly hasn't left us empty handed either. We forged connections with so many dutiful, diverse stewards representing nonprofits, schools, and community organizations, all committed to keeping their communities fed.

We forge ahead: to serve as connectors, to process and plan for how we can continue to get good food to food insecure communities where funding may be hard to come by. We continue to innovate and to serve our traditional wholesale audiences, many of whom remained connected despite the disturbances caused by the pandemic. Many gracefully resurfaced, little by little.

COVID-19 has positioned our resilient spirits and will to rise to the surface. We witnessed how partnerships within the regional food system ignited meaningful impact and met the needs of those who are most vulnerable.

"The Common Market has saved many lives in the community by supplying food to those in need," shared Derrick Ford of Brothers of Strawberry Mansion, a USDA Farmers to Families recipient.

And for now, we move forward in our mission to serve.

\section{References}

City of New York. (2020, July 21). Mayor de Blasio announces city has distributed 100 million meals to New Yorkers since March. Retrieved from http://www1.nyc.gov/office-of-the-mayor/news/533-20/mayor-de-blasio-city-hasdistributed-100-million-meals-new-yorkers-since-march-calls

Kenneally, B. A. (2020, September 2). America at hunger's edge. The New York Times. https://www.nytimes.com/interactive/2020/09/02/magazine/food-insecurity-hunger-us.html

\footnotetext{
${ }^{1}$ https://www.ams.usda.gov/selling-food-to-usda/farmers-to-families-food-box
} 